\title{
The development of the thermal tourism market in Poland
}

\section{Rozwój rynku turystyki termalnej w Polsce}

\author{
Diana Dryglas ${ }^{1}$, Andrzej Hadzik ${ }^{2}$ \\ ${ }^{1} A G H$ University of Science and Technology, \\ Faculty of Geology, Geophysics and Environmental Protection, Department of General Geology and Geotourism, \\ al. A. Mickiewicza 30, 30-059 Krakow; \\ e-mail:ddryglas@agh.edu.pl \\ ${ }^{2}$ School of Banking in Poznań, Faculty in Chorzów, Department of Tourism and Recreation, \\ ul. Sportowa 29, 41-506 Chorzów; \\ e-mail:Andrzej_Hadzik@wp.pl
}

\begin{abstract}
Thermal tourism in Poland has been gaining in popularity for over a decade now. This refers to both the supply and demand sides of the market. Therefore, the aim of this paper is to describe the current situation, as well as the prospects of formation and development of the thermal tourism market in Poland. To do that, a number of research methods had to be employed, including a critical analysis of literature on the subject, statistical data analysis, a case study (the example of Poland), methods of observation and inference by deduction within the scope of the research question asked. Based on the results of secondary research and an in-depth review of literature on the subject, one can conclude that Polish thermal tourism market is not growing steadily. On the one hand, there is considerable consumers' interest in using geothermal pools, while on the other the geothermal potential for medical and recreational purposes remains unexploited.
\end{abstract}

Key words: geothermal waters, thermal tourism, thermal tourism market, Poland

Treść: Od kilkunastu lat turystyka termalna w Polsce cieszy się coraz większa popularnościa. Stąd też celem artykutu jest próba nakreślenia obecnej sytuacji oraz perspektyw powstania i rozwoju rynku turystyki termalnej $w$ Polsce. Realizacja celu pracy wymagała zastosowania kilku metod badawczych, takich jak krytyczna analiza literatury przedmiotu, analiza danych statystycznych, studium przypadku (przykład Polski), metody obserwacji, oraz wnioskowania przez dedukcje $w$ zakresie postawionego pytania badawczego. Na podstawie wyników badań wtórnych i dogłębnego przegladu literatury przedmiotu można stwierdzić, ̇̇e rynek turystyki termalnej rozwija się nierównomiernie. Bowiem z jednej strony mamy do czynienia z dużym zainteresowaniem konsumentów korzystaniem z basenów geotermalnych z drugiej zaś obserwuje się niewykorzystany potencjat geotermalny mogacy stużć do celów leczniczych i rekreacyjnych.

Stowa kluczowe: wody geotermalne, turystyka termalna, rynek turystyki termalnej, Polska

\section{Introduction}

Despite the still marginal global use of geothermal energy (1.5\%) (BP Statistical World Energy Review, 2015), the importance of geothermal waters is invaluable when compared with other renewable energy sources (Polish: OZE, Odnawialne Źródła Energii). This is demonstrated by their various application that developed with the evolution of civilisation. Initially, these resources were used only for physiological purposes. Then, people would use them in sanitation and gastronomy, and much later, they became a form of treatment and recreation. At present, they constitute economic and energy resources (Kępińska, Łowczowska, 2002). The information presented during the World Geothermal Congress in 2015 indicates that there is constant development in the field of global geothermal water use (Kępińska, 2015). According to the data presented by Kępińska (2010), space heating constitutes the largest share in global use of geothermal waters. Thermal pools and balneotherapy rank second. In Poland, however, direct use of geothermal waters constitutes only $0.2 \%$ (Kępińska, 2013), in spite of the fact that nearly $90 \%$ of Poland is located in the area of geothermal deposits (Górecki, Hajto, 2008; Kępińska, 2016). Heat engineering is the main area of geothermal water use. Therapeutics and recreation, in turn, are less common in that respect (Kępińska, 2016), together representing around 7\% of direct geothermal water use in Poland (Hałaj, 2012). In 2016, there were nine statutory spa resorts in Poland (Cieplice Śląskie-Zdrój, Lądek-Zdrój, Duszniki-Zdrój, Ciechocinek, Konstancin-Jeziorna, Ustroń, Iwonicz-Zdrój, Rabka-Zdrój, Uniejów), seven geothermal bathing and recreation centres in the Podhale region (Aqua Park Zakopane and the geothermal bathing pool Szymoszkowa in Zakopane; Termy Szaflary, Termy Gorący Potok in Szaflary; Terma Bukovina; Terma Białka, Termy Chochołowskie), and four in the Polish Lowlands (Termy Mszczonów, Geotermia Grudziądz, Geotermia Poddębice, Termy Maltańskie in Poznań) and Termy Warmińskie in Lidzbark Warmiński, which use geothermal water for medical, recreational and heating purposes.

In the light of the arguments above and in face of the dynamic development of the thermal tourism market in Poland's neighbour countries, that is Hungary and Slovakia, discussed extensively in the literature on the subject (e.g. Dej et al., 2013a,b), the following question arises: how can we describe the development the thermal tourism market in Poland? The present paper is an attempt to answer this question by providing an outline of the current situation and the prospects of formation and development of the thermal tourism market in Poland.

\section{Historical overview of thermal tourism}

The use of geothermal waters in tourism (in therapeutics and recreation) has a long history and several-thousand year 
old tradition. It is also integrated into the development of both material and spiritual heritage of a number of civilisations (Cataldi et al., 1999). The origins of thermal tourism reach back into the times of the following ancient civilisations: Indian (3000-1700 years BC, the Indus Valley), Chinese (1050771 years BC, Huaqing), Greek (the 8th century BC) and Roman (the 1st century BC). Their philosophy of life involved strong links with nature (Erfurt-Cooper, Cooper, 2009).

In Europe, it was the Turks who were the precursors of thermal tourism (for the purpose of this paper, Turkey has been included in Europe in accordance with the division adopted by the UN-World Tourism Organisation). Turkey has a long history of using natural thermal resources for medical purposes, dating back to the period between 1680 and $1193 \mathrm{BC}$, when the Hittite emperor used hot springs in the region of Anatolia for recreational and medical purposes (there are over 700 hot springs there that are in use today) (Erfurt-Cooper,Cooper, 2009, p. 65). Later, people travelled to Greece for medical purposes to use Greek hot springs (thermal waters in Thermae, today's Loutraki) (Fytikas et $a l ., 1999)$ and to Italy (thermal waters in Northern Italy used by the Etruscans) (Cataldi, Burgassi, 1999). Greek mythology abounds in legends about the relation between thermal springs and deities such as: Artemis Thermia, the patroness of all springs; Thermios Apollo, who would use thermal waters to cure ills; or Naiades, the nymph guardians of spa resorts (Katsambas, Antoniou, 1996). Several classical authors such as: Homer (the 9th/8th century BC), Plato (427347 BC), Aristotle (384-322 BC) or Pliny the Elder (23-79 $\mathrm{AD})$ refer to the advantages of thermal waters in their works (Cataldi et al., 1999, p. 147-164). However, the culture of having baths was first created in ancient Rome. Baths themselves, including thermal ones, became a form of art. Inspired by Etruscans (from the 8th to the 6th century BC), and by Greeks from the time of conquests, Roman thermae (from the Greek "heat"), i.e. thermal care centres, began to emerge (Melillo, 1995). The first thermae were opened at the turn of the 1st century BC in Pompeii (Erfurt-Cooper, Cooper, 2009, p. 52). One can say that such facilities constitute an archetype for contemporary aqua parks and thermal spa resorts. In subsequent years, more and more thermae were established, and they were more glamorous and larger. For instance, the thermae built for Emperor Caracalla were capable of accommodating over 1.6 thousand Romans. However, it was the Baths of Diocletian (where over 6 thousand people could have a bath simultaneously) that went down in history as the largest thermae (Mihina, Anderson, 2010, p. 4).

Roman baths consisted of two parts: the palestra and the thermae. The first part served the body, and the other one was for maintaining purity. The palestra comprised extensive gyms, an open courtyard and other open spaces for recreational physical activities. These included activities resembling today's running, swimming, tennis, weightlifting, boxing, wrestling and handball. That part of Roman baths also included a number of shops, libraries, museums and places that looked like present-day restaurants and bars offering a wide range of food and beverages.
Thermae constituted the proper service area of the bathing facility and consisted of the following parts (Erfurt-Cooper, Cooper, 2009, p. 63; Mihina, Anderson, 2010, p. 4; Smith, Puczkó, 2009, p. 25):

- changing rooms (apodyterium);

- cold water pools (frigidarium);

- hot water pools (caldarium) and a cold water fountain for cooling, today's steam bath;

- bathhouses: dry bath (laconicum);

- chambers for massage and 'anointing' the body with oil (oleoterion);

- rest chamber (tepidarium).

Roman baths were public. Poor Romans also had an access to them for a small fee. They would enable the citizens of Rome to improve their physical fitness, culture and hygiene (especially at the beginning). Owing to Roman conquests, the above mentioned culture, including the culture of bathing, could reach new areas of the then Empire. The development of thermal tourism was also connected with well developed (at that time) road routes. This had a significant influence on the fact that tourism became more popular in ancient Rome than in ancient Egypt or Greece (Kowalczyk, 2001).

However, the relatively well developed infrastructure of paved roads and inns would not have had any effect on the development of thermal tourism in ancient Rome if there had not been geothermal waters, that is hot springs, in the area of the then Empire (Krasiński, 2001). In the said Empire, waters were used for hygienic, recreational and social purposes in the first place, only then were they used for medical purposes (Dryglas, 2006). However, it should be emphasised that Romans would look after their health and travel to spa resorts. They appreciated not only medicinal-thermal water, but also potable water (Łazarek, Łazarek, 2007).

The greatest number of baths was created at the time of the Roman Republic (106-48 BC). In 180 AD, there were around 800 free-of-charge baths in the capital of the Empire, that is Rome. During the rule of Domitian, Trajan, Diocletian and Titus, these were the most eminent buildings in Rome. They were erected together with libraries, gyms, theatres and ballrooms. The entire complex was surrounded by columns and gardens (Smith, Puczkó, 2009).

Roman thermal resorts were located across the then Empire wherever geothermal waters were found (Kowalczyk, 2001). Romans would build thermal spa resorts both in Italy and in the provinces. In ancient times, the most well-known resorts were: Aurelia Aquensis or Aquae (today's BadenBaden, Germany), Aquae Matticae (Wiesbaden, Germany), Aquae Calidae (today's Vichy, France), Aquae Solis (the Bath resort in the United Kingdom), Aquae Helveticae (Baden, Switzerland), Aquae Herculi (Baile Herculane, Romania) and Stabae Terme, Sirmione, Abano Terme, Baiae and Caracalla Thermal Baths in Italy (Kowalczyk, 2001; Kurek 2007).

The Roman province of Pannonia (today's Hungary) is one of the areas of the former Roman empire with excellent natural conditions for the development of thermal tourism 
(both in ancient times and at present) (Łazarek, Łazarek, 2007). Some thermae built in one of Europe's richest areas in terms of geothermal water springs have survived in Hungary to the present day, the example being the thermal pools in Aquincum and Romai Furdo in Budapest. Today, over 130 geothermal water springs are used there.

The first written evidence of the existence of hot springs in the territory of present-day Poland is over 700 years old and refers to the area of today's Sudety Mountains. In Cieplice Śląskie-Zdrój, in turn, the first bathing pool in Poland was created in 1409. Facts from the following years concern the Szczawno and Lądek-Zdrój resorts. From the 11th to the 14 th century, steam and water treatments in baths were popular among Slavs, including those in the current territory of Poland. However, from the 15 th century on the baths were being closed in many towns and cities due to the belief that such facilities contributed to the spread of numerous diseases (Sallmann, 2010).

In the Middle Ages, the interest in balneological resorts declined, mainly under the influence of the Church, and thus the significance of therapeutic use of thermal waters for carnal pleasure decreased. The contemporary Christians, who would prefer asceticism and mortification, often perceived thermal resorts as "places of merriment and immorality" (Krasiński, 2004). In the period analysed, healing springs were associated mainly with supernatural healing powers and people would build sanctuaries in their vicinity, thus fulfilling the religious purpose in the first place (Bacon, 1998). Therefore, for about ten centuries only a few people would travel for health purposes in medieval Europe, e.g. to the areas "ruled" by Turks. Inspired by the Roman culture of thermal baths, Turks created their own philosophy of bathing with the use of public baths called "hammam" (Smith, Puczkó, 2009).

The perception of baths (including the thermal ones) in Europe began to change in the 18th century. At that time, a number of physicians acknowledged on the basis of scientific evidence that such therapies could support the healing process (Alonso-Álvarez, 2012). In Europe, the resort model that stood out was the English model represented by the then largest European spa resort (Bath). The resort was established because geothermal waters were found in that area (Kowalczyk, 2001). In the summer season of the 18th century, its average number of visitors topped 12 thousand people. Apart from Bath, the following health resorts continued to develop: Bagni di Lucca, Montecatini (Italy), Marienbad, Karlsbad (the territory of the present-day Czech Republic), Spa (Belgium), Baden-Baden (Germany), Pfäfers (Switzerland), Barèges and Bagnères-de Bigorre in the Pyrenees (France), as well as Aix-les-Bains and Evian in the Alps (France) (Warszyńska, Jackowski, 1978).

At the end of the 18th century, and especially, the beginning of the 19th century, Europe saw an exponential growth of spa tourism, which also used thermal waters. At that time, Europe enjoyed relative peace. That was also the time of the Industrial Revolution visible in rapid changes not only in technology, but also in the social-economic sphere of life (Dryglas, 2006). In the 19th century, "travels to waters" took place on an unprecedented scale. Well-developed European spa resorts were tourist and healing reception centres for the then aristocratic, landed gentry and emerging capitalist bourgeoisie elites. Health considerations, in turn, were only a complement to the desire of entertainment (Krasiński, 2001). Apart from that, "travels to waters" constituted an alternative for areas without any significant tourist attractions such as recognised buildings of historical and architectural interest, palaces or castles (Ślusarczyk, 2003).

Clear progress in hydrotherapy and balneology also had a significant impact on further development of thermal tourism. Vincenz Priessnitz (1799-1851), a peasant farmer from the Sudety Mountains, was one of the people who contributed to the development of balneological knowledge (Ponikowska, 1995). The spa resorts he created would accommodate around 2 thousand guests per year. Physicians employed in these resorts administered hydrotherapeutic baths, packs and showers under the guidance of master Priessnitz himself (the so-called Priessnitz compresses). At that time, another prominent expert in hydrotherapeutic treatment was a Bavarian priest Sebastian Kneipp (1821-1897), who based his treatment method on the healing power of nature. He proved experimentally that hydrotherapeutic treatment influences key biological processes (Ciszewski, 1988). His hydrotherapeutic methods are still popular today in the form of a special system of treatment and establishment of spa resorts that operate in accordance with the Kneipp method in Germany. Joseph Dietl, father of the Polish scientific balneology, contributed to the development of spa resorts in 19th-century Poland (Kochański, 2002). He believed that spa treatment should be justified through scientific research, endorsing balneoclimatic treatment and spa tourism at the same time. In 1858, upon the initiative of J. Dietl, the Balneological Commission established the "Spółka Zdrojowisk Krajowych" (English: a partnership of national resorts) - the first industrial-economic organisation of Polish spa resorts (Ciszewski, 1988). In its early days, the partnership united spa resorts in Galicia, and from 1859 - all state resorts.

In $19^{\text {th }}$-century Europe, the resorts that experienced spectacular growth included: Baden, Vichy, Karlovy Vary, Marienbad, Bagnere-de-Bigorne, Aix-les-Bains, Bath, Spa (Kurek, 2007). Apart from that, other renowned European resorts included: Bad Hamburg, Sopot, Świnoujście (formerly in Germany), or Bad Ischl. Krasiński (2004) estimates that $90 \%$, that is nearly one thousand, of spa resorts operating in Europe nowadays were created in the second half of the 19th century.

Medical progress of the beginning of the 20th century meant that pharmacology, facilitating effective and fast treatment, outdistanced balneology (including thermal hydrotherapy). That was tantamount to the limitation of the role of hydrotherapy in treatment. At the same time, such therapies became more important in regular body and beauty care. In the 1960s and 1970s, first health and beauty farms were established (e.g. in Austria). Meanwhile, spa resorts were transformed into luxurious spa and wellness hotels. In Poland, geothermal waters were used mainly for healing purposes in Cieplice Śląskie-Zdrój, Lądek-Zdrój and in certain water intakes in Ciechocinek and Iwonicz-Zdrój till the end of the 1970s (Latour, 
Smętkiewicz, 2012). Moreover, in the second half of the 20th century, discoveries of geothermal water deposits were often accidental. This often happened by chance, as a result of drilling for crude oil and natural gas (e.g. in Uniejów, a borehole in Marusza for Geotermia Grudziądz). According to Krasiński (2004), the contemporary local authorities were not particularly interested in the discoveries of geothermal waters.

At present, hot healing waters in the form of geothermal waters are used in Poland, apart from the already mentioned resorts, in the following statutory spa resorts: Ustron, Konstancin-Jeziorna, Rabka-Zdrój, Duszniki-Zdrój and Uniejów (Kępińska, 2013). Moreover, in the Podhale region or in the Polish Lowland, among others, geothermal investments have been made in recent years to use the springs for the development of thermal tourism.

\section{Definition of thermal tourism}

As the definition of geothermal waters is ambiguous, it is not easy to define thermal tourism. A coherent and universal definition of geothermal waters has not been developed in source literature to date. According to some authors, geothermal waters are ground waters with temperature exceeding the annual average air temperature in a given area (e.g. Jaroszewski et al., 1985). Others, in turn, believe that geothermal waters are waters of temperature over $20^{\circ} \mathrm{C}$. This belief is based on human perception of heat (Chowaniec, 2013). Apart from that, the term "geothermal waters" is interpreted according to the provisions of country-specific geological legislation.
For instance, the Japanese (Erfurt-Cooper, Cooper, 2009) and Korean law (Seung-Kyung, 1996) define geothermal water as water of at least $25^{\circ} \mathrm{C}$. In Italy, in turn, geothermal waters are divided into cold (below $20^{\circ} \mathrm{C}$ ); hypothermal $\left(20-30^{\circ} \mathrm{C}\right)$, thermal $\left(30-40^{\circ} \mathrm{C}\right)$ and hyperthermal (over $40^{\circ} \mathrm{C}$ ) (Andreassi, Flori, 1996), whereas in Spain - into cold $\left(12-18^{\circ} \mathrm{C}\right)$, fresh $\left(18-27^{\circ} \mathrm{C}\right)$, neutral $\left(27-32^{\circ} \mathrm{C}\right)$, warm $\left(32-36.5^{\circ} \mathrm{C}\right)$, hot $\left(37-40^{\circ} \mathrm{C}\right)$ and very hot $\left(40-43^{\circ} \mathrm{C}\right)($ Ledo, 1996). In Poland, the Geological and Mining Law of 2011 defines geothermal waters as underground waters whose temperature at the outlet is at least $20^{\circ} \mathrm{C}$ (Ustawa $\mathrm{z}$ dnia 9 czerwca 2011 r. Prawo geologiczne i górnicze). Due to its thermal conditions, Poland is dominated by low-temperature geothermal waters (of low enthalpy), that is of temperature below $150^{\circ} \mathrm{C}$. In most cases, these are deposits that are extracted at the depth of 1-3.5 km with subsurface temperature of $20-95^{\circ} \mathrm{C}$ (Kępińska, 2016). In Poland, there are currently nine statutory spa resorts using geothermal waters for treatment purposes, with maximum temperature at the outflow of around $19-44^{\circ} \mathrm{C}$. In the case of Iwonicz-Zdrój, Duszniki-Zdrój and Konstancin-Jeziorna, temperatures at the outflow are usually lower than $20^{\circ} \mathrm{C}$, which is the reason why the water is heated for treatment (Kępińska, 2013). Three of the spa resorts mentioned above (i.e. Cieplice Śląskie-Zdrój, Lądek-Zdrój, and Duszniki-Zdrój) use water from natural springs, whereas the other resorts use water extracted from boreholes. Geothermal waters in the Podhale region and in the Polish Lowland have higher temperatures (of 27-95 ${ }^{\circ}$ ) (Chowaniec et al., 2001; Kępińska, 2013) due to a favourable geological structure (Chowaniec, 2007; Biernat et al., 2011).

Tab. 1. Geothermal waters' characteristics (own compilation based on Erfurt-Cooper, Cooper, 2009; Latour, Smętkiewicz, 2012; Omulecki et al., 1996) - Charakterystyka wód geotermalnych (opracowanie własne na podstawie Erfurt-Cooper, Cooper, 2009; Latour, Smętkiewicz, 2012; Omulecki et al., 1996)

\begin{tabular}{|c|c|c|c|}
\hline $\begin{array}{l}\text { Properties/ } \\
\text { Właściwości }\end{array}$ & $\begin{array}{l}\text { Therapies/ } \\
\text { Zastosowanie }\end{array}$ & $\begin{array}{c}\text { Indications/ } \\
\text { Wskazania }\end{array}$ & $\begin{array}{l}\text { Contraindications/ } \\
\text { Przeciwwskazania }\end{array}$ \\
\hline $\begin{array}{c}\text { highly warming, } \\
\text { antibacterial, anti-inflamma- } \\
\text { tory } \\
\text { immunosuppressive, } \\
\text { diuretic, } \\
\text { improving metabolism } \\
\text { stimulating blood supply to } \\
\text { the skin / } \\
\text { silnie rozgrzewajace, } \\
\text { antybakteryjne, przeciw- } \\
\text { zapalne, } \\
\text { immunosupresyjne, } \\
\text { moczopędne, } \\
\text { wody poprawiajq ukrwienie } \\
\text { skóry, przemianę materii }\end{array}$ & $\begin{array}{l}\text { lukewarm baths (temp. to } \\
34^{\circ} \mathrm{C} \text { ), warm baths (temp. of } \\
34-38^{\circ} \mathrm{C} \text { ), hot baths (to } 43^{\circ} \mathrm{C} \text { ), } \\
\text { power showers, pouring, } \\
\text { aromatic baths, pearl baths } \\
\text { and inhalations / } \\
\text { kapiele letnie (temp. do } 34^{\circ} \mathrm{C} \text { ), } \\
\text { kapiele ciepłe (temp. } 34-38^{\circ} \mathrm{C} \text { ), } \\
\text { kapiele gorqce }\left(\text { do } 43^{\circ} \mathrm{C}\right), \\
\text { natryski, polewania, kqpiele } \\
\text { aromatyczne i perełkowe, } \\
\text { inhalacje }\end{array}$ & $\begin{array}{l}\text { musco-skeletal diseases, spinal } \\
\text { disorders, chronic arthritis, neu- } \\
\text { ralgias, paralyses, dermatological } \\
\text { diseases, psoriasis, urinary tract } \\
\text { disorders, allergies of respiratory } \\
\text { system, gynecological diseases, } \\
\text { obesity, vegetative neuroses, } \\
\text { cardiovascular diseases, hyper- } \\
\text { tension, periodontium diseases / } \\
\text { choroby narządu ruchu, kręgosłu- } \\
\text { pa, chroniczne zapalenie stawów, } \\
\text { nerwobóle, paraliże, choroby } \\
\text { skóry, układu moczowego, alergie } \\
\text { układu oddechowego, choroby } \\
\text { ginekologiczne, otyłość, nerwice } \\
\text { wegetatywne, choroby układu } \\
\text { krażenia (takie jak nadciśnienie), } \\
\text { choroby przyzębia oraz skóry, np. } \\
\text { łuszczycy }\end{array}$ & $\begin{array}{c}\text { circulatory failure, heart } \\
\text { diseases, pregnancy, active } \\
\text { tuberculosis, malignant } \\
\text { tumors, inflammatory condi- } \\
\text { tions, massive varicose veins, } \\
\text { suppurative changes, hypo- } \\
\text { tension / } \\
\text { niewydolność krążenia, } \\
\text { choroby serca, ciąża, czynna } \\
\text { gruźlica, nowotwory złośliwe, } \\
\text { stany zapalne, masywne żylaki, } \\
\text { zmiany ropne na skórze, osoby } \\
\text { z niskim ciśnieniem }\end{array}$ \\
\hline
\end{tabular}


Geothermal waters are highly stimulating and often contain hydrogen sulphide, silica and fluorides (Kępińska, Ciągło, 2008). Stimulation by hot waters causes vasodilatation, improves the blood flow and lowers blood pressure. Moreover, it leads to the secretion of noradrenaline, cortisol, the growth hormone and endorphin derivatives (Koźmiński et al., 2013). Geothermal waters are often crystal clear and they are rich in minerals including a number of elements necessary for the proper functioning of the human body. These include iron, potassium, manganese, silicon, magnesium, sulphur, chromium, lithium, selenium, and calcium (Chowaniec et al., 1997; Omulecki et al., 1996). A bath in mineralised water has a number of benefits - it improves heartbeat, boosts metabolism, stabilises heart rate, reduces stress levels, regulates hormonal system, eliminates myalgia and arthralgia, helps to overcome insomnia, stabilises the nervous system, helps to recover from surgery and other motor organ disorders (Kochański, 2002; Karski et al., 2000). Regular baths in thermal pools protect even from old age diseases, especially from Alzheimer's and Parkinson's diseases. Besides, a bath in such water is highly relaxing (Tab. 1). The use of geothermal water depends on the elements it contains and the ailments to be treated. For instance: saline water reduces hypertension, treat skin and cardiovascular diseases; sulphide-fluoride water is indicated in cases of stress or neurosis, but it also treats joint diseases, orthopaedic disorders and diseases of the nervous system. The effects of thermal baths depend on a number of factors, including duration of a bath, additional mechanical stimulation (shower bath or water movement), the movement of the bather (e.g. while swimming), changes in water temperatures during treatment and chemical composition of water (Latour, Smętkiewicz, 2012).

Due to the fact that every type of geothermal water has the qualities of healing water, meeting the physical (temperature) and chemical criteria (content of soluble specific chemical ingredients) (Stanik et al., 2011), thermal tourism can be considered a form of health tourism, which has been emphasised by Erfurt-Cooper and Cooper in literature on the subject (2009). Thus, thermal tourism involves a conscious and voluntary decision to leave for at least one day (an overnight stay), but for no longer than a year, in one's free time, to a place where geothermal waters of temperature of at least $20^{\circ} \mathrm{C}$ at the outflow are found and are used for various healing and prophylactic treatments. Thermal tourism can have the form of visiting spa resorts, tourist resorts with thermal facilities, or spa centres.

\section{Characteristics of thermal tourism market}

The global thermal tourism market has a significant potential and extensive reach (Tab. 2). On the one hand, thermal tourism market includes tourists travelling for various health purposes; on the other one - companies operating in the thermal tourism market. The common ground for the two groups is the thermal tourism product that satisfies the needs (the demand side) and can be provided (the supply side) at a price and quality tailored to both these groups and adjusted to the market.

Given various health purposes of thermal tourism, four main groups of tourists can be identified (Das Profil der Wellness, 2004). These are tourists taking the following types of holidays:

- wellness holidays, focusing on psycho-physical relaxation and restoring strength and vitality;

- beauty holidays, focusing on therapies and treatments improving one's looks;

- health care holidays, focusing on methods and therapies preventing or mitigating diseases, as well as treating various psychological or physical dysfunctions;

- anti-aging holidays, focusing on maintaining or improving mental health or physical fitness, as well as effectively combating detrimental habits.

Research carried out over 10 years (2003-2013) on samples of tourists staying at Polish spa resorts (2003 - sample of 1988 tourists (Dryglas, 2006); 2005 - sample of 3461 tourists (Burzyński et al., 2005), and 2013 - sample of 2050 tourists (Dryglas, Różycki, 2016)), indicated that thermal pools constitute the most desirable tourist attraction. On the other hand, an in-depth review of literature on the subject concerning the supply side of thermal tourism points to a relatively low dynamics of its development. This is reflected by a relatively small number of health resorts in Poland using geothermal waters for therapeutic purposes (merely $20 \%$, that is 9 out of 45) in spite of the fact that Polish tradition of using geothermal waters in health resorts can be traced back to the 12th century. Legend says that the foundation of the Cieplice Śląskie-Zdrój resort is connected with the discovery of hot springs made by Prince Boleslav IV in 1175 while hunting (Zieliński, 1983, p. 33).

For many years, geothermal waters have been used for therapeutic purposes in seven statutory spa resorts in Poland: Cieplice Śląskie-Zdrój, Lądek-Zdrój, Duszniki-Zdrój, Ciechocinek, Konstancin-Jeziorna, Ustroń, Iwonicz-Zdrój (Kępińska, 2013) and, recently, that is since 2011, in Rabka-Zdrój and since 2012, in Uniejów (the only thermal spa resort in Poland). Research conducted by Szromek and Kapczyński (2010), based on eighteen criteria grouped in seven categories, revealed that the best locations for new thermal health resorts in Poland will be: Zakopane, Cieplice Śląskie-Zdrój, Ustroń, Słomniki and Ciechocinek. Moreover, Poland has a small number of thermal centres (14) compared to Hungary or Slovakia, which started to emerge in 2006 - Geotermia Grudziądz and Aqua Park in Zakopane; 2007 geothermal bathing pool Szymoszkowa in Zakopane; 2008 - Terma Bukovina, Termy Szaflary, Termy Mszczonów; Termy Uniejów; 2011 - Terma Białka; 2012 - Geotermia Poddębice; 2013 - Termy Maltańskie in Poznań; 2014 - Termy Cieplickie, 2015 - Termy Gorący Potok in Szaflary; 2016 - Termy Chochołowskie, Termy Warmińskie in Lidzbark Warmiński (Fig. 1). 
The development of the thermal tourism market in Poland

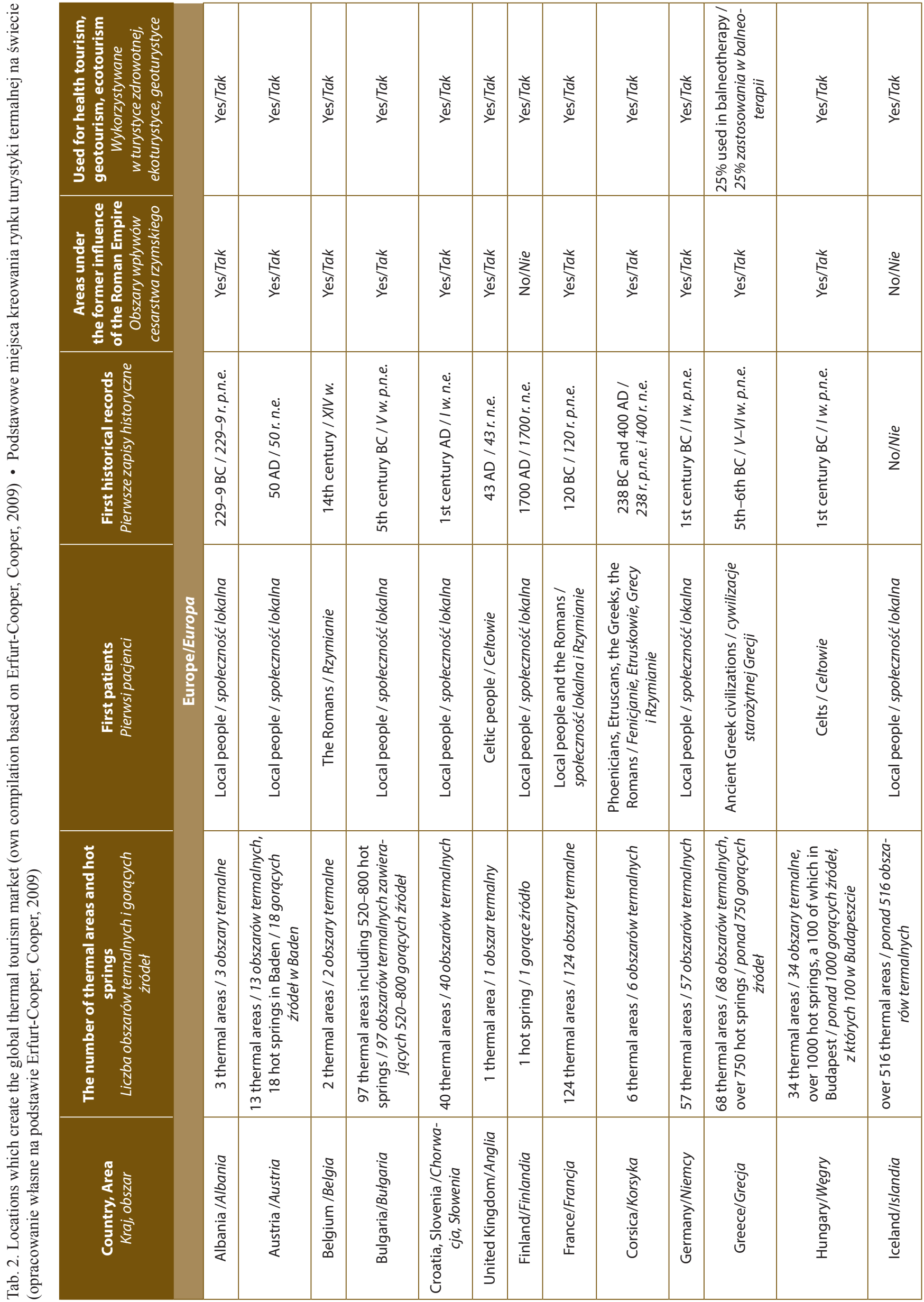




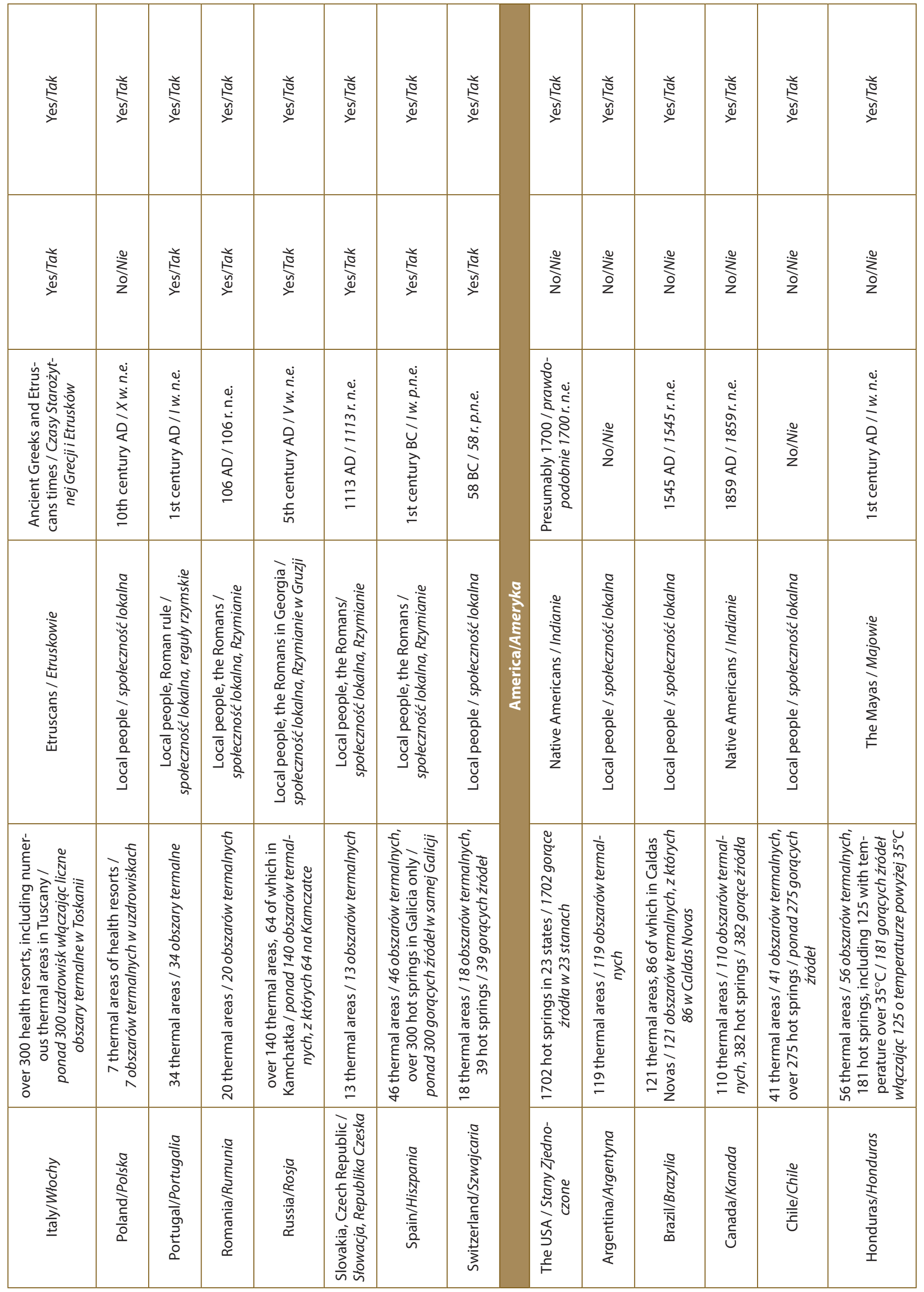


The development of the thermal tourism market in Poland

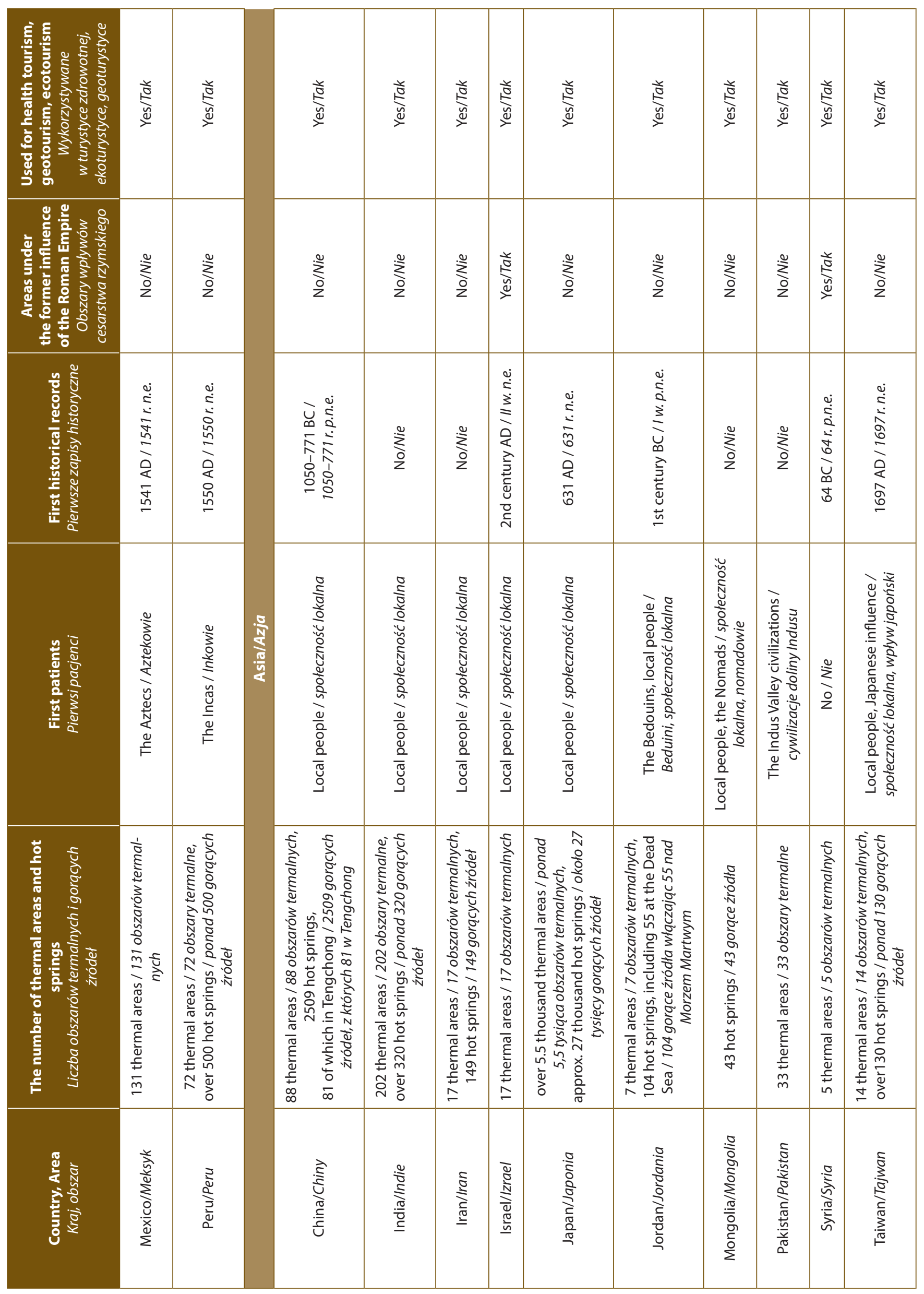




\begin{tabular}{|c|c|c|c|c|c|c|c|c|c|c|c|c|c|c|}
\hline 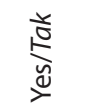 & 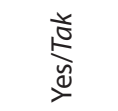 & 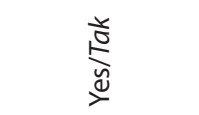 & है & & 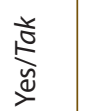 & 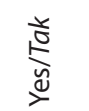 & $\frac{\frac{v}{5}}{\stackrel{y}{y}}$ & 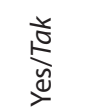 & 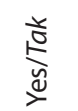 & & $\frac{\frac{r}{v}}{\frac{\tilde{y}}{\check{d}}}$ & 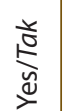 & 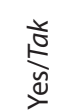 & 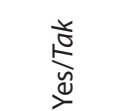 \\
\hline$\underset{\substack{z \\
z}}{\stackrel{y}{z}}$ & $\underset{z}{\stackrel{y}{z}}$ & 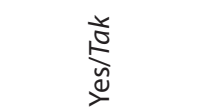 & है & & $\begin{array}{l}\sum_{0}^{\circ} \\
\frac{0}{z}\end{array}$ & $\begin{array}{l}\sum_{0}^{\circ} \\
\text { zon }\end{array}$ & $\underset{\substack{z \\
z}}{\stackrel{y}{z}}$ & $\frac{\frac{v}{5}}{\stackrel{y}{\nu}}$ & 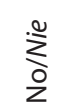 & & 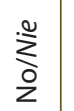 & 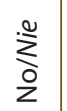 & $\underset{\frac{o}{z}}{z}$ & 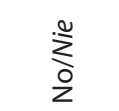 \\
\hline 竞 & 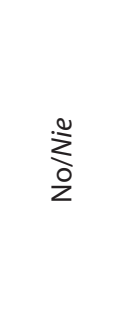 & 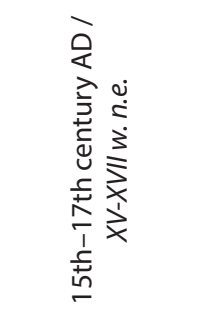 & 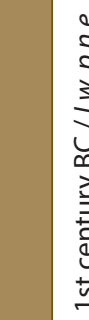 & & 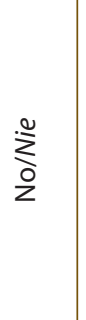 & 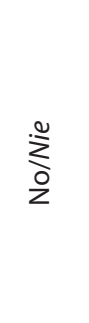 & $\begin{array}{l}\sum_{0}^{0} \\
z\end{array}$ & 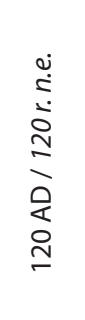 & $\begin{array}{l}\sum_{0}^{0} \\
\text { z }\end{array}$ & & $\begin{array}{l}\stackrel{u}{z} \\
\stackrel{0}{z}\end{array}$ & 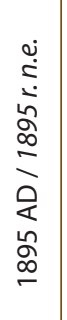 & $\begin{array}{l}\sum_{0}^{u} \\
\dot{0}\end{array}$ & 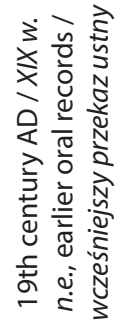 \\
\hline 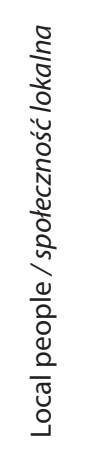 & 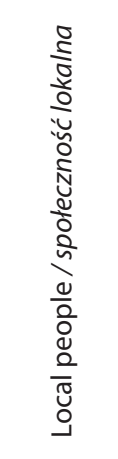 & 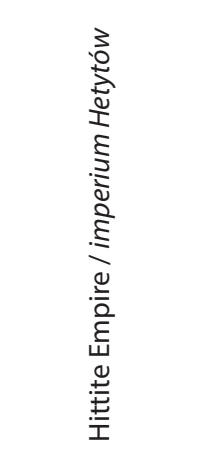 & 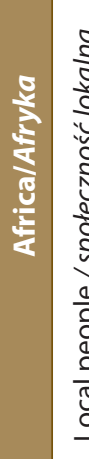 & & 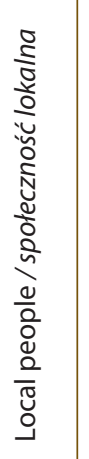 & 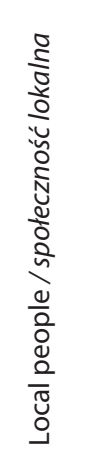 & 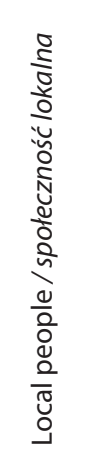 & 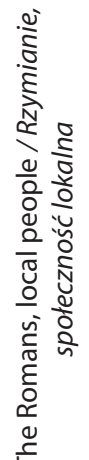 & 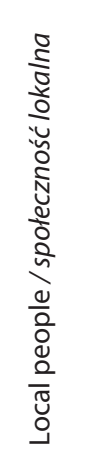 & 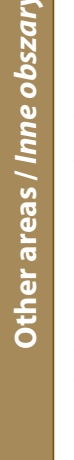 & 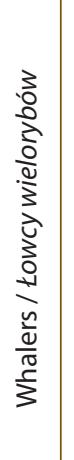 & 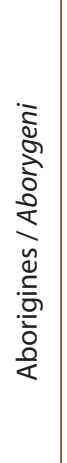 & 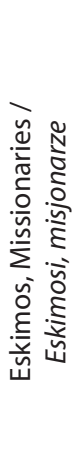 & 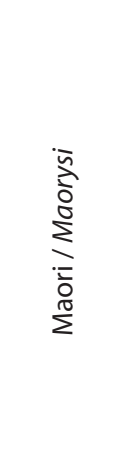 \\
\hline 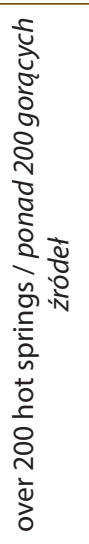 & 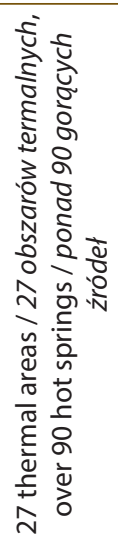 & 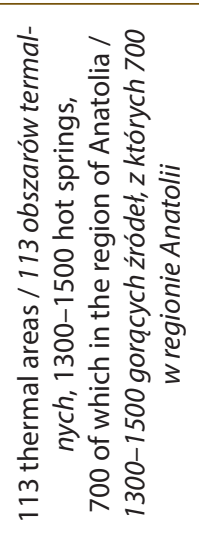 & 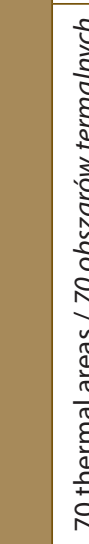 & 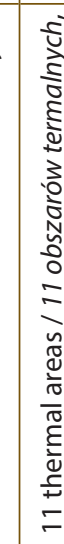 & 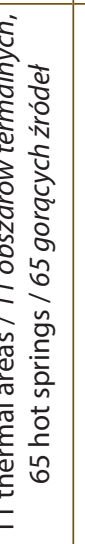 & 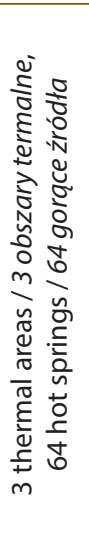 & 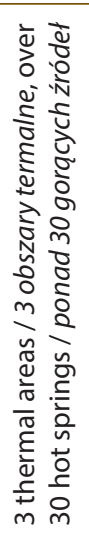 & 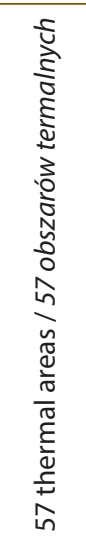 & 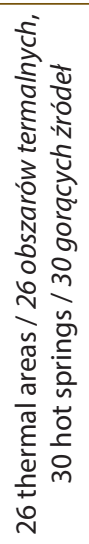 & & 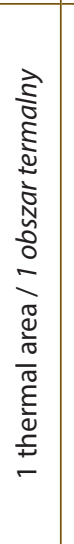 & 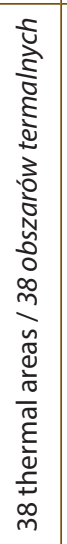 & 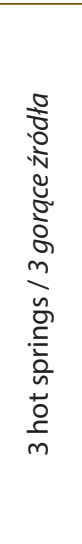 & 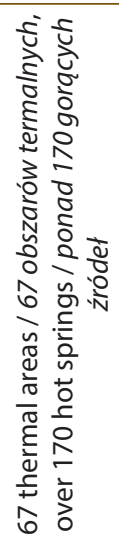 \\
\hline 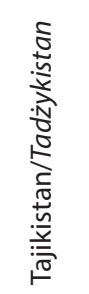 & 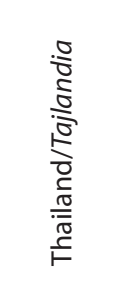 & 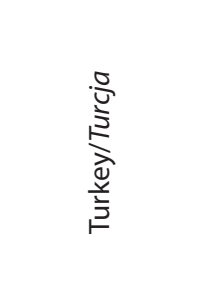 & 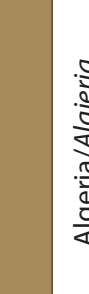 & & 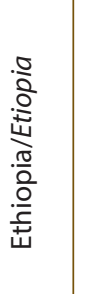 & 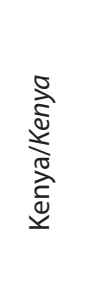 & 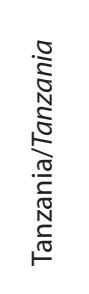 & 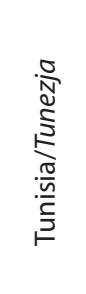 & 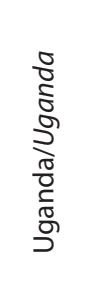 & & 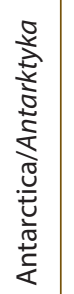 & 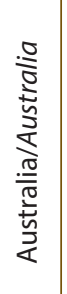 & 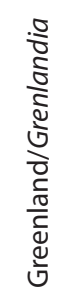 & 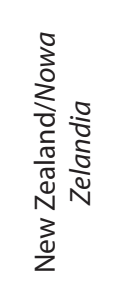 \\
\hline
\end{tabular}


It is worth emphasizing, that historically the first was the geothermal bathing pool in Jaszczurówka, with geothermal water discovered by Ludwik Zejszner in 1844 (Zejszner, 1844). Despite numerous drilling activities commissioned by the Polish state authorities in the second half of the 20th century, resulting in geothermal water discoveries, e.g. in Marusza near Grudziądz (1972) or in Uniejów (1978), the market of thermal resorts in Poland is still relatively new.

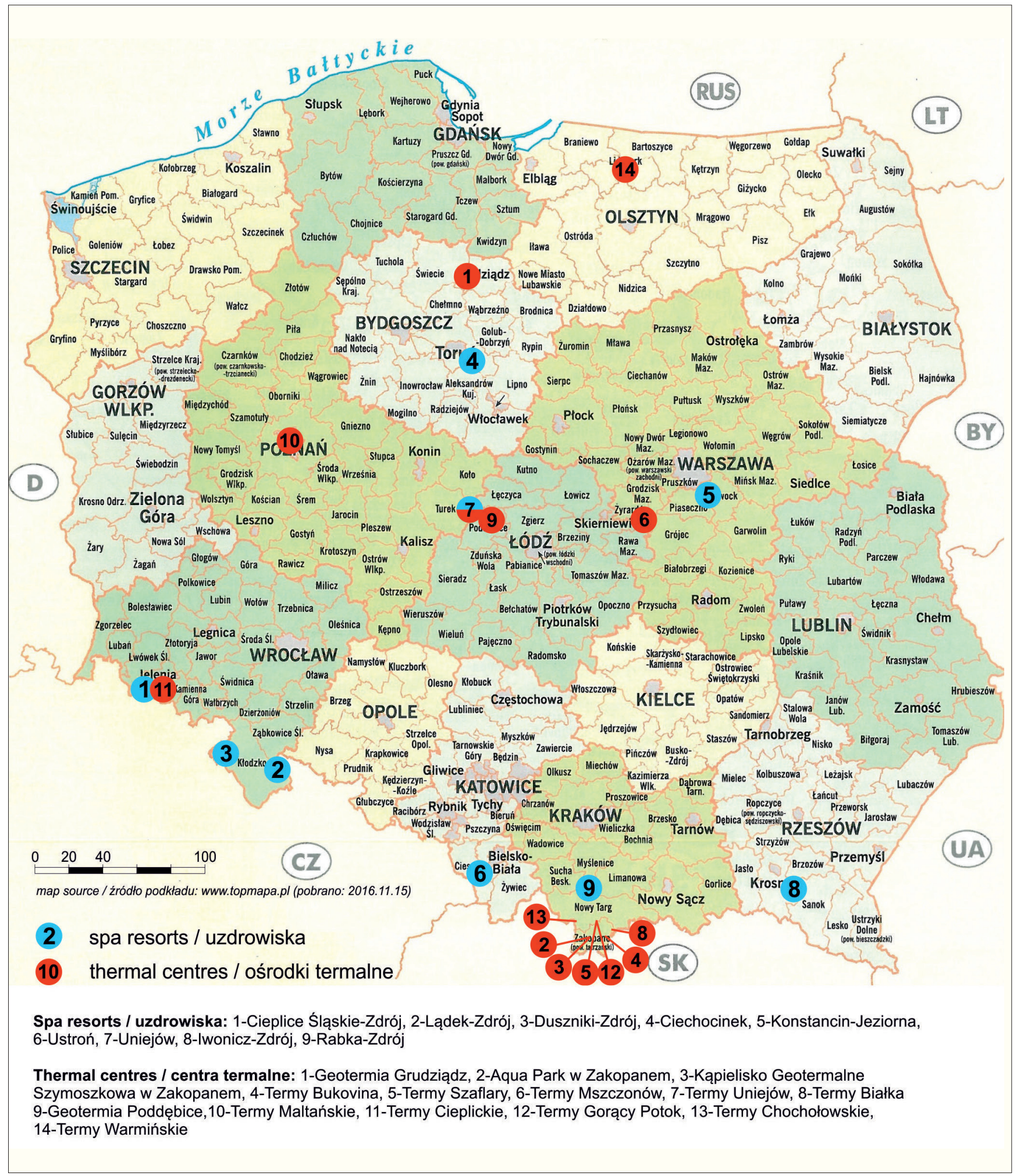

Fig. 1. Location of statutory spa resorts using geothermal water and thermal centres in Poland (own compilation, map source: www.topmapy.pl) - Lokalizacja uzdrowisk statutowych wykorzystujących wodę geotermalną i ośrodków termalnych w Polsce (opracowanie własne, źródło podkładu: www.topmapy.pl). 
On the other hand, the development of the thermal tourism market in terms of quality requires thorough scientific research. So far, such research has been conducted by the market leader, the infobasen.pl portal, which focuses on thermal centres. Table 3 presents a proposal of an online ranking, which might raise some doubts and encourage remarks. However, the authors have decided to present this ranking to reveal quality leaders in the market of thermal tourism in Poland, even though the figures presented are only estimates.

Tab. 3. Ranking of companies in possession of thermal pools in Poland (source: www. infobasen.pl) • Ranking przedsiębiorstw mających baseny termalne w Polsce (źródło: www.infobasen.pl)

\begin{tabular}{|c|c|c|c|c|c|}
\hline \multirow{2}{*}{ Company / Przedsiębiorstwo } & \multirow{2}{*}{$\begin{array}{c}\text { Ranking } \\
\text { place / } \\
\text { Miejsce } \\
\text { w rankingu }\end{array}$} & \multirow{2}{*}{$\begin{array}{c}\text { Overall } \\
\text { rating*/ } \\
\text { Ocena } \\
\text { ogólna }\end{array}$} & \multicolumn{3}{|c|}{ Criteria / Kryteria } \\
\hline & & & $\begin{array}{l}\text { Facilities/ } \\
\text { Udogodnienia }\end{array}$ & $\begin{array}{l}\text { Cleanliness/ } \\
\text { Czystość }\end{array}$ & $\begin{array}{l}\text { Service/ } \\
\text { Obsługa }\end{array}$ \\
\hline Terma Białka & 1 & 8,3 & 7,3 & 7,5 & 7,0 \\
\hline Termy Maltańskie & 2 & 7,9 & 7,2 & 6,9 & 7,1 \\
\hline Baseny Mineralne Solec-Zdrój & 3 & 7,8 & 8,0 & 8,1 & 7,0 \\
\hline Termy Uniejów & 4 & 7,7 & 7,7 & 7,7 & 7,0 \\
\hline Termy Bukowina Tatrzańska & 5 & 7,7 & 6,7 & 6,8 & 6,3 \\
\hline Termy Cieplickie & 6 & 7,5 & 4,3 & 4,3 & 3,8 \\
\hline Aqua Park Zakopane & 7 & 7,3 & 7,5 & 7,9 & 5,9 \\
\hline Warmia Park Termy Medical Aquapark & 8 & 7,1 & 7,6 & 7,2 & 6,6 \\
\hline Termy Mszczonów & 9 & 6,4 & 5,2 & 5,6 & 5,3 \\
\hline Termy Podhalańskie & 10 & 5,9 & 6,6 & 6,7 & 5,9 \\
\hline Inowrocławska Terma & 11 & 5,8 & 6,2 & 7,0 & 7,2 \\
\hline Przedsiębiorstwo Uzdrowiskowe Ustroń S.A. & 12 & 5,4 & 5,0 & 5,8 & 4,6 \\
\hline Geotermia Grudziądz & 13 & 5,1 & 3,6 & 4,4 & 4,8 \\
\hline $\begin{array}{l}\text { Roman baths in the Palace of Saturn / } \\
\text { Termy Rzymskie w Pałacu Saturna }\end{array}$ & 14 & 5,0 & 5,0 & 5,0 & 5,0 \\
\hline $\begin{array}{l}\text { Turkish bath at Sanatorium Zdrój Wojciech / } \\
\text { Łaźnia Turecka w Sanatorium Zdrój Wojciech }\end{array}$ & 15 & 4,7 & 8,1 & 7,1 & 6,3 \\
\hline $\begin{array}{c}\text { Geothermal bathing pool Szymoszkowa in } \\
\text { Zakopane / Kapielisko Geotermalne Szymosz- } \\
\text { kowa w Zakopanem }\end{array}$ & 16 & 4,2 & 9,0 & 9,0 & 8,0 \\
\hline
\end{tabular}

* The overall rating consists of the following: from $50 \%$ to $70 \%$ of attractions, from $30 \%$ to $50 \%$ internet users' assessment. Percentage weight depends on the number of opinions. Ranking points: scale from 0 to 10.

* Na ocene sktadaja się: od 50\% do 70\% atrakcje basenu, a od 30\% do 50\% ocena internautów. Waga procentowa oceny jest uzależniona od liczby opinii. Ranking. ocena $w$ skali od 0 do 10. 


\section{Conclusions}

Balneotherapy, also with the use of geothermal waters, has evolved from empiricism in natural sciences practiced by people without any theoretical basis to a science currently cultivated in numerous centres by qualified staff. Thermal tourism is characterised by complex and complementary use of treatments based on geothermal water. Modern knowledge has proven that geothermal waters are important for human health and constitute a development trend in a number of tourist resorts.

For thermal tourism to develop, it is necessary that both sides of the market that is the demand side and the supply side develop evenly. Excessively dynamic development of only one of them can significantly hinder the development of the market of thermal tourist services. Survey results (Dryglas, 2006; Burzyński et al., 2005; Dryglas, Różycki, 2016) have confirmed the need to use thermal pools in Polish spa resorts, but the analysis of the literature on the subject has indicated that the supply of thermal tourist services is not adjusted to the demand in terms of the number and construction time of thermal facilities in statutory spa resorts (only two thermal facilities: in Uniejów and in Cieplice Śląskie-Zdrój), and in other tourist destinations (12 thermal facilities in 10 years). Such status quo could entail serious long-term ramifications for the relatively young market of thermal tourism and its stakeholders. For this reason, strengthening the supply side of the market (construction of thermal facilities) seems to be one of the key challenges. Facing this challenge will enable further development of the market in Poland.
The development of thermal tourism in Poland is stimulated by:

- relevant geothermal resources (Kępińska, 2016);

- tradition and history of geothermal water use for therapeutic and recreational purposes;

- legal circumstances related to geothermal water exploration, construction of thermal centres and geothermal water use (Dej et al., 2013a; Polityka resortu $w$ dziedzinie hydrologii na lata 2008-2015, 2008);

- health care trend;

- "bath fad", i.e. popularity of thermal baths as a new way of spending leisure time (Dej et al., 2013a)

On the other hand, the obstacles in the development of thermal tourism include high costs of geothermal investment (e.g. Płochniewski, 1990), which discourage potential investors from taking action. However, geothermal undertakings can be subsidised by/with:

- the National Fund for Environmental Protection and Water Management

- the Fund's financial means from environmental charges and penalties;

- the EkoFundusz foundation;

- low interest loans from Bank Ochrony Środowiska (English: Environmental Protection Bank)

In spite of the obstacles mentioned above, there are plans for new investments in geothermal infrastructure (e.g. Termy Gostynińskie, Lubelskie Termy in Celejów), which is broadly described in the work by Stanik et al. (2011).

\section{Streszczenie}

\section{Rozwój rynku turystyki termalnej w Polsce}

\section{Diana Dryglas, Andrzej Hadzik}

Mimo wciąż marginalnego wykorzystania energii geotermalnej na świecie (1,5\%) (BP Statistical World Energy Review, 2015) w porównaniu z innymi odnawialnymi źródłami energii (OZE), znaczenie wód geotermalnych jest nie do przecenienia. Świadczą o tym różne sposoby ich zastosowania, które rozwijały się wraz z rozwojem cywilizacji. Początkowo złoża te służyły jedynie do celów fizjologicznych, następnie znalazły zastosowanie w higienie i gastronomii, znacznie później stało się formą leczenia i rekreacji, a obecnie są zasobem ekonomicznym i surowcem energetycznym (Kępińska, Łowczowska, 2002). Z informacji przedstawionych podczas Światowego Kongresu Geotermalnego w 2015 r. wynika, że następuje ciągły rozwój wykorzystania wód geotermalnych na świecie (Kępińska, 2015). Zgodnie z danymi prezentowanymi przez Kępińską (2010) największy udział w skali świata pod względem bezpośredniego wykorzystanie wód geotermalnych ma ogrzewanie pomieszczeń, a na drugim miejscu znajdują się kąpieliska i balneoterapia. Natomiast w Polsce bezpośrednie wykorzystanie wód geotermalnych kształtuje się zaledwie na poziomie 0,2\% (Kępińska, 2013), mimo że Polska prawie w 90\% leży w obszarze złóż geotermalnych (Górecki, Hajto, 2008; Kępińska, 2016). Główną dziedziną wykorzystania wód geotermalnych jest ciepłownictwo, zaś sporadycznie lecznictwo i rekreacja (Kępińska, 2016), stanowiące łącznie około $7 \%$ bezpośrednich zastosowań wód geotermalnych w Polsce (Hałaj, 2012). W 2016 r. działało dziewięć uzdrowisk statutowych w Polsce (Cieplice Śląskie-Zdrój, Lądek-Zdrój, Duszniki-Zdrój, Ciechocinek, Konstancin-Jeziorna, Ustroń, Iwonicz-Zdrój, Rabka-Zdrój, Uniejów), siedem ośrodków geotermalnych na Podhalu (Aqua Park i Kąpielisko Geotermalne Szymoszkowa w Zakopanem; Termy Szaflary, Termy Gorący Potok w Szaflarach; Terma Bukovina; Terma Białka, Termy Chochołowskie), cztery na Niżu Polskim (Termy Mszczonów, Geotermia Grudziądz, Geotermia Poddębice, Termy Maltańskie w Poznaniu) oraz Termy Warmińskie w Lidzbarku Warmińskim. Wszystkie te ośrodki wykorzystują wodę geotermalną zarówno w celach leczniczych, rekreacyjnych i grzewczych.

W kontekście powyższych argumentów oraz w konfrontacji z dynamicznym rozwojem rynku turystyki termalnej u naszych sąsiadów na Węgrzech i Słowacji, szeroko omówionym w literaturze przedmiotu (np. Dej et al., 2013a,b) nasuwa się pytanie, jak rozwija się rynek turystyki termalnej 
w Polsce. Stąd też celem artykułu jest próba nakreślenia obecnej sytuacji oraz perspektyw powstania i rozwoju rynku turystyki termalnej w Polsce w związku z postawionym pytaniem.

Zdefiniowanie pojęcia turystyki termalnej nie jest łatwe ze względu na niejednoznaczność definicji wód geotermlanych. Do tej pory w literaturze $\mathrm{z}$ tego zakresu nie wypracowano spójnej i powszechnie obowiązującej definicji wód geotermalnych. Według niektórych autorów za wody geotermalne uważa się wody podziemne o temperaturze przekraczającej średnią roczną temperaturę powietrza na danym obszarze (np. Jaroszewski et al., 1985). Z kolei inni, na podstawie wrażenia ciepła odczuwanego przez człowieka, za wody geotermalne przyjmują wody o temperaturze powyżej $20^{\circ} \mathrm{C}$ (Chowaniec, 2013). Ponadto podstawę rozumienia pojęcia wód geotermalnych w poszczególnych krajach stanowią przepisy prawne z zakresu prawa geologicznego. Na przykład zgodnie z prawem japońskim (Erfurt-Cooper, Cooper, 2009) i koreańskim (Seung-Kyung, 1996) za wodę geotermalną uznaje się wodę, której temperatura wynosi minimum $25^{\circ} \mathrm{C}$. Z kolei we Włoszech wody geotermalne dzieli się na zimne - poniżej $20^{\circ} \mathrm{C}$, hipotermalne $-20-30^{\circ} \mathrm{C}$, termalne $-30-40^{\circ} \mathrm{C}$ i hipertermalne - powyżej $40^{\circ} \mathrm{C}$ (Andreassi, Flori, 1996), a w Hiszpanii na zimne $-12-18^{\circ} \mathrm{C}$, świeże $-18-27^{\circ} \mathrm{C}$, neutralne $-27-32^{\circ} \mathrm{C}$, ciepłe $-32-36,5^{\circ} \mathrm{C}$, gorące $-37-40^{\circ} \mathrm{C}$ i bardzo gorące $-40-43^{\circ} \mathrm{C}$ (Ledo, 1996). Natomiast w Polsce zgodnie z uchwalonym w 2011 r. prawem geologicznym i górniczym wody geotermalne zdefiniowano jako wody podziemne, które na wypływie z ujęcia mają temperaturę nie mniejszą niż $20^{\circ} \mathrm{C}$ (Ustawa z dnia 9 czerwca 2011 r. Prawo geologiczne i górnicze). W Polsce wody lecznicze, swoiste, o temperaturze wyższej niż $20^{\circ} \mathrm{C}$ i równej lub niżej niż $35^{\circ} \mathrm{C}$ podobnie jak we Włoszech noszą nazwę wód hipotermalnych, wody o temperaturze wyższej niż $35^{\circ} \mathrm{C}$ i równej lub niżej niż $40^{\circ} \mathrm{C}$ określane są jako wody homeotermalne, a wody o temperaturze powyżej $40^{\circ} \mathrm{C}$ nazywane są wodami hipertermalnymi. Warunki termiczne powodują, że w Polsce dominują wody geotermalne niskotemperaturowe (o niskiej entalpii), czyli wody o temperaturach poniżej $150^{\circ} \mathrm{C}$, najczęściej są to złoża eksploatowane na głębokości $1-3,5 \mathrm{~km}$ o temperaturze wgłębnej w zakresie około $20-95^{\circ} \mathrm{C}$ (Kępińska, 2016). Obecnie działa w kraju dziewięć uzdrowisk statutowych stosujących wody geotermalne w lecznictwie, gdzie maksymalne temperatury wód na wypływach wynoszą od około $19^{\circ} \mathrm{C}$ do $44^{\circ} \mathrm{C}$. W przypadku Iwonicza-Zdroju, Dusznik-Zdroju i Konstancina-Jeziornej temperatury wód na wypływach są zazwyczaj niższe niż $20^{\circ} \mathrm{C}$, dlatego też są one podgrzewane do zabiegów (Kępińska, 2013). Powyższe uzdrowiska korzystają w trzech przypadkach z wód ujętych w naturalnych źródłach (Cieplice Śląskie-Zdrój, Lądek-Zdrój, Duszniki-Zdrój), a pozostałe z wód wydobywanych otworami wiertniczymi. Wyższe temperatury osiągają wody geotermalne na Podhalu i Niżu Polskim, w zakresie $27-95^{\circ} \mathrm{C}$ (Chowaniec et al., 2001; Kępińska, 2013), ze względu na korzystną budowę geologiczną (Chowaniec, 2007; Biernat et al., 2011).

Wody geotermalne są wodami silnie oddziałującymi, nierzadko zawierającymi siarkowodór, krzemionkę i fluorki (Kępińska, Ciągło, 2008). Stymulacja gorącymi wodami wpływa na rozszerzenie naczyń krwionośnych, poprawę przepływu krwi i obniżenie ciśnienia tętniczego, ponadto wydziela się noradrenalina, kortyzol, hormon wzrostu oraz pochodne endorfin (Koźmiński et al., 2013). Wody geotermalne są często krystalicznie czyste i charakteryzują się bogatym składem mineralnym, obejmującym wiele pierwiastków niezbędnych do prawidłowego funkcjonowania organizmu. Należą do nich m.in.: żelazo, potas, mangan, krzem, magnez, siarka, chrom, lit, selen, wapń (Chowaniec et al., 1997; Omulecki et al., 1996). Kąpiel w zmineralizowanej wodzie niesie ze sobą mnóstwo korzyści - usprawnia pracę serca, podwyższa metabolizm, stabilizuje tętno, obniża poziom stresu, reguluje gospodarkę hormonalną w organizmie, eliminuje bóle mięśniowe i stawów, pomaga pokonać bezsenność, stabilizuje system nerwowy, pomaga powrócić do zdrowia po operacjach oraz innych schorzeniach narządu ruchu (Kochański, 2002; Karski et al., 2000). Regularne kąpiele w basenach termalnych chronią nawet przed dolegliwościami wieku podeszłego, zwłaszcza przed chorobą Parkinsona i Alzheimera. Ponadto kąpiel w takiej wodzie to solidna dawka relaksu. Przeznaczenie wody geotermalnej zależy od obecnych w niej pierwiastków i dolegliwości, którą chcemy wyleczyć. Przykładowo wody solankowe redukują nadciśnienie, leczą choroby skóry i krążenia, a wody siarczkowo-fluorkowe są wskazaniami w przypadku narażenia na stres czy nerwice, leczą także choroby stawów, schorzenia ortopedyczne oraz choroby układu nerwowego. Ogólną charakterystykę wód geotermalnych pokazano w tabeli 1. Efekty oddziaływania kąpieli termalnych zależą od wielu czynników, w tym od czasu trwania kąpieli, dodatkowych bodźców mechanicznych (natrysk czy ruch wody), ruchu - aktywności osoby korzystającej z kąpieli (np. pływanie), zmian temperatury wody w czasie zabiegu oraz składu chemicznego wody (Latour, Smętkiewicz, 2012).

Ze względu na fakt, że każda woda geotermalna odznacza się cechami wód leczniczych, spełniając kryteria fizyczne (temperatura) oraz chemiczne (zawartość rozpuszczonych swoistych składników chemicznych) (Stanik et al., 2011), można zaliczyć turystykę termalną do jednej z form turystyki zdrowotnej, co podkreślali między innymi w literaturze przedmiotu Erfurt-Cooper i Cooper (2009). Zatem turystyka termalna obejmuje świadomy i dobrowolny wyjazd co najmniej na dzień (z noclegiem) i nie dłużej niż na rok, w czasie wolnym, do miejsc występowania i wykorzystania źródeł wód geotermalnych o temperaturze nie mniejszej na wypływie niż $20^{\circ} \mathrm{C}$ do różnorakich zabiegów o charakterze leczniczym oraz profilaktycznym. Są to więc podróże do uzdrowisk i innych miejscowości turystycznych mających na swoim terenie ośrodki termalne czy ośrodki spa.

Światowy rynek turystyki termalnej ma znaczący potencjał i rozległy zasięg, co zobrazowano w tabeli 2. Rynek turystyki termalnej to $\mathrm{z}$ jednej strony turyści podróżujący w różnorakich celach zdrowotnych, a z drugiej podmioty gospodarcze turystyki termalnej. Tym, co łączy obydwie grupy, jest adekwatny pod względem potrzeb (strona popytowa) i możliwości wykreowania (strona podażowa) produkt turystyki termalnej po odpowiednich dla jednej i drugiej strony oraz dostosowanych do tego rynku cenie i jakości. 
Uwzględniając różne cele zdrowotne wyjazdów w ramach turystyki termalnej, można współcześnie wyróżnić cztery główne grupy turystów (Das Profil der Wellness, 2004). Są to turyści wyjeżdżający w ramach tzw.:

- wakacji relaksujących ( $\mathrm{z}$ ang. wellness holidays), gdy celem wyjazdu jest odpoczynek psychofizyczny i przywrócenie organizmowi człowieka sił i witalności;

- wakacji piękności (z ang. beauty holidays), bazujących na programach terapii i usług poprawiających wygląd turystów;

- wakacji leczniczych (z ang. health care holidays), podczas których stosowane są metody i terapie zapobiegające lub łagodzące stany chorobowe oraz odbywa się leczenie różnorakich dysfunkcji psychofizycznych;

- wakacji odmładzających (z ang. anty-aging holidays, pozwalających utrzymać lub poprawić kondycję psychofizyczną, a także skutecznie walczyć z negatywnymi dla zdrowia nawykami.

Badania prowadzone na przestrzeni dziesięciu lat, w 2003 r. (Dryglas, 2006) na próbie 1988 turystów, następnie w 2005 r. na próbie 3461 turystów (Burzyński et al., 2005 ) oraz w 2013 r. na próbie 2050 turystów (Dryglas, Różycki, 2016), przebywających w polskich uzdrowiskach, wykazały, że baseny termalne stanowią najbardziej pożądaną atrakcję turystyczną. Z kolei dogłębny przegląd literatury przedmiotu w zakresie podaży turystyki termalnej wskazuje na stosunkowo niską dynamikę jej rozwoju. Odzwierciedleniem takiego stanu rzeczy jest jak dotąd stosunkowo niewielka liczba uzdrowisk polskich (zaledwie 20\%, 9 z 45) wykorzystujących wody geotermalne w celach leczniczych, mimo że tradycje wykorzystania wód geotermalnych w polskich uzdrowiskach sięgają XII wieku. Według legendy powstanie uzdrowiska Cieplice Śląskie-Zdrój jest związane z odkryciem gorących źródeł przez księcia Bolesława IV w 1175 r., podczas polowania (Zieliński, 1983, p. 33).

Obecnie od wielu lat wykorzystuje się wody geotermalne w celach leczniczych w siedmiu uzdrowiskach statutowych: Cieplice Śląskie-Zdrój, Lądek-Zdrój, Duszniki-Zdrój, Ciechocinek, Konstancin-Jeziorna, Ustroń, Iwonicz-Zdrój (Kępińska, 2013), a od niedawna, bo dopiero od 2011 w Rabce-Zdroju i od 2012 w Uniejowie, które jest jedynym uzdrowiskiem termalnym w Polsce. Badania przeprowadzone przez Szromka i Kapczyńskiego (2010), oparte na osiemnastu kryteriach pogrupowanych w siedem sekcji, ujawniły, że najbardziej optymalnymi lokalizacjami uzdrowisk termalnych w Polsce będą: Zakopane, Cieplice Śląskie-Zdrój, Ustroń, Słomniki i Ciechocinek. Ponadto w Polsce występuje nieznaczna liczba ośrodków termalnych (14) w porównaniu do ich liczby na Węgrzech czy Słowacji, które zaczęły powstawać dopiero od 2006 r. - Geotermia Grudziądz i Aqua Park w Zakopanem; 2007 r. - Kąpielisko Geotermalne Szymoszkowa w Zakopanem; 2008 r. - Terma Bukovina, Termy Szaflary, Termy Mszczonów, Termy Uniejów; 2011 r. - Terma Białka; 2012 r. - Geotermia Poddębice; 2013 r. - Termy Maltańskie w Poznaniu; 2014 r. - Termy Cieplickie; 2015 r. - Termy Gorący Potok w Szaflarach; 2016 r. - Termy Chochołowskie, Termy Warmińskie w Lidzbarku Warmińskim (Fig. 1). Na uwagę zasługuje fakt, że historycznie pierwsze było kąpielisko geotermalne na Jaszczurówce z wodą geotermalną odkrytą przez Ludwika Zejsznera w 1844 r. (Zejszner, 1844). Pomimo wykonania licznych odwiertów na zlecenie polskich władz państwowych w II połowie XX w., których efektem było znalezienie wód geotermalnych na przykład w miejscowości Marusza niedaleko Grudziądza (1972 r.) czy w Uniejowie (1978 r.), rynek ośrodków termalnych jest stosunkowo młodym rynkiem w Polsce, rozwijającym się dopiero od kilku lat.

Natomiast rozwój rynku turystyki termalnej pod względem jakościowym wymaga przeprowadzenia gruntownych badań przez naukowców. Do tej pory badania w tym zakresie przeprowadza wiodący w branży termalnej portal infobasen.pl, który koncentruje się na ośrodkach termalnych. W tabeli 3 przedstawiono jedną z propozycji rankingu internetowego, który jak zawsze w przypadku tego typu ocen może budzić pewne wątpliwości i uwagi. Jednakże autorzy zdecydowali się pokazać ten ranking w celu szacunkowego ujawnienia liderów jakości rynku turystyki termalnej w Polsce.

Medycyna balneologiczna, w tym związana $\mathrm{z}$ wodami geotermalnymi, dość długo ewoluowała od całkowitej empirii w przyrodoznawstwie, uprawianej przez nierzadko nieprzygotowane osoby, do nauki stosowanej obecnie w wielu ośrodkach przez wykwalifikowaną kadrę. Istota turystyki termalnej polega na kompleksowym i komplementarnym stosowaniu zabiegów opartych na wodzie geotermalnej. Współczesna wiedza udowadnia, że wody geotermalne mają znaczenie zdrowotne dla człowieka, a jednocześnie stanowią czynnik warunkujący rozwój wielu ośrodków turystycznych.

Dla rozwoju turystyki termalnej konieczne jest, aby obydwie strony rynku, tj. strona popytowa oraz strona podażowa, ewoluowały równomiernie, bowiem zbyt dynamiczny wzrost tylko jednej z nich może istotnie zahamować aktywność na rynku usług turystyki termalnej. O ile wyniki badań ankietowych (Burzyński et al., 2005; Dryglas, 2006; Dryglas, Różycki, 2016) potwierdziły potrzebę korzystania z basenów termalnych w polskich uzdrowiskach, o tyle analiza literatury przedmiotu wykazała niedostosowanie do wymagań popytu podaży usług turystyki termalnej pod względem liczby i tempa budowy obiektów termalnych zarówno w uzdrowiskach statutowych (jedynie dwa obiekty termalne - w Uniejowie i Cieplicach Śląskich-Zdroju), jak i w pozostałych miejscowościach turystycznych (12 obiektów termalnych na przestrzeni 10 lat). Utrzymywanie w długim okresie takiego stanu rzeczy mogłoby pociągnąć za sobą poważne dla stosunkowo młodego rynku turystyki termalnej i jego uczestników konsekwencje. Z tego względu wzmocnienie podażowej strony rynku (budowa obiektów termalnych) wydaje się obecnie jednym z kluczowych wyzwań, którego podjęcie umożliwi dalszy jego rozwój w Polsce. 
Czynnikami, które stymulują rozwój turystyki termalnej w Polsce, są:

- odpowiednie zasoby geotermalne (Kępińska, 2016);

- tradycje i historia wykorzystania wód geotermalnych do celów leczniczych i rekreacyjnych;

- uwarunkowania prawne związane z eksploatacją wód geotermalnych, budową ośrodków termalnych oraz wykorzystaniem wód geotermalnych (Dej et al., 2013a; Polityka resortu w dziedzinie hydrologii na lata 2008-2015, 2008);

- tendencja związana z dbałością o zdrowie,

- popularność tego typu aktywności jako nowego sposobu spędzania wolnego czasu (Dej et al., 2013a).

Z kolei wśród przeszkód w rozwoju turystyki termalnej najczęściej wymienia się wysokie koszty inwestycji geotermalnych (np. Płochniewski, 1990), które odstraszają wielu potencjalnych inwestorów. Jakkolwiek istnieją możliwości dofinansowania przedsięwzięć geotermalnych:

- z Narodowego Funduszu Ochrony Środowiska i Gospodarki Wodnej;

- ze środków funduszu pochodzących z opłat i kar za korzystanie ze środowiska;

- ze wsparcia Fundacji EkoFundusz;

- z kredytów niskooprocentowanych z Banku Ochrony Środowiska.

Mimo wskazanej wyżej bariery planowane są nowe inwestycje w zakresie infrastruktury geotermalnej (np. Termy Gostynińskie, Lubelskie Termy w Celejowie), o czym szerzej piszą w swoim artykule Stanik et al. (2011).

\section{References (Literatura)}

Alonso-Álvarez L., 2012. The value of water: the origins and expansion of thermal tourism in Spain. Journal of Tourism History, 4(1): 15-34.

Andreassi L., Flori L., 1996. Mineral water and spas in Italy. Clinics in Dermatology, 14(6): 627-632.

Bacon W., 1998. Economic systems and their impact on tourist resort development: the case of the Spa in Europe. Tourism Economics, 4(1): 21-32.

Biernat H., Kapuściński J., Noga B., Martyka P., 2011. Przegląd realizowanych i planowanych projektów wykorzystania wód i energii geotermalnej na Niżu Polskim. Materiały III. Ogólnopolskiego Kongresu Geotermalnego, Lądek-Zdrój 28-30 września 2011.

BP Statistical World Energy Review. Available from: http:/www.bp.com/ en/global/corporate/energy-economics/statistical-review-of-world-energy/2015-in-review.html [accessed: 2016.08.15].

Burzyński T., Dryglas D., Golba J., Bartosik A., 2005. Czynniki wpływajace na jakość $i$ konkurencyjność ustug turystycznych $w$ miejscowościach uzdrowiskowych (Factors affecting the quality and competitiveness of tourism services in spa resorts). Institute of Tourism in Krakow, Association of Polish Spa Communities, Kraków.

Cataldi R., Burgassi P.D., 1999. Flowering and decline of thermal bathing and other uses of natural heat in the Mediterranean area, from the birth of Rome to the end of the first Millennium. In: Cataldi R., Hodgson S., Lund J. (eds.), Stories from a heated Earth. Our geothermal heritage, Geothermal Resources Council \& International Geothermal Association, Sacramento, California: 147-164.

Cataldi R., Hodgson S., Lund J. (eds), 1999. Stories from a heated Earth. Our geothermal heritage. Geothermal Resources Council \& International Geothermal Association, Sacramento, California.

Chowaniec J., 2007. Niecka podhalańska - najbardziej perspektywiczny zbiornik wód termalnych w polskich Karpatach. Wspótczesne Problemy Hydrogeologii, 13(3): 931-938.

Chowaniec J., 2013. Obieg wody w skali regionalnej Tatr i Podhala ze szczególnym uwzględnieniem fazy podziemnej. In: Pociask-Karteczka J. (ed.), Z badań hydrologicznych $w$ Tatrach, Tatrzański Park Narodowy, Zakopane: 63-70.

Chowaniec J., Długosz P., Drozdowski B., Nagy S., Poprawa D., Witczak S., Witek K., 1997. Dokumentacja hydrogeologiczna wód termalnych niecki podhalańskiej. Centralne Archiwum Geologiczne, Państwowy Instytut Geologiczny, Warszawa.

Chowaniec J., Poprawa D., Witek K., 2001. Występowanie wód termalnych w polskiej części Karpat. Przegląd Geologiczny, 49(8): 734-742.

Ciszewski F., 1988. Polskie lecznictwo uzdrowiskowe w XIX wieku z uwzględnieniem uzdrowiskowego leczenia chorób reumatycznych. Problemy Uzdrowiskowe, 11-12: 253-254.

Das Profil der Wellness - Reisenden. 2004. Institut Für Freizeitwirtschaft, Monachium.

Dej M., Huculak M., Jarczewski W., 2013a. Recreational use of geothermal water in Visegrad Group countries. Institute of Urban Development, Krakow.
Dej M., Huculak M., Jarczewski W., 2013b. Recreational use of geothermal water in Poland and Slovakia. Current Issue of Tourism Research, 1: $12-21$.

Dryglas D., 2006. Ksztattowanie produktu turystycznego uzdrowisk w Polsce. Wydawnictwo Uniwersytetu Jagiellońskiego, Kraków.

Dryglas D., Różycki P., 2016. European spa resorts in the perception of non-commercial and commercial patients and tourists: the case study of Poland. e-Review of Tourism Research, 13(1-2): 382-400.

Erfurt-Cooper P., Cooper M., 2009. Health and Wellness Tourism: spas and hot springs. Aspects of Tourism, 40. Channel View Publications, Bristol, UK.

Fytikas M., Leonidopoulou G.M., Cataldi R., 1999. Geothermal energy in ancient Greece: From mythology to late antiquity (3rd century AD). In: Cataldi R., Hodgson S., Lund J. (eds), Stories from a heated Earth. Our geothermal heritage. Geothermal Resources Council \& International Geothermal Association, Sacramento, California: 69-102.

Górecki W., Hajto M., 2008. Atlas zasobów geotermalnych na Niżu Polskim. Akademia Górniczo-Hutnicza w Krakowie, Wydział Geologii, Geofizyki i Ochrony Środowiska, Zakład Surowców Energetycznych, Kraków.

Hałaj E., (2012). Kąpieliska i ośrodki wypoczynkowe na Podhalu i Niżu Polskim jako przykłady bezpośredniego wykorzystania wód geotermalnych w Polsce. Technika Poszukiwań Geologicznych, Geotermia, Zrównoważony Rozwój, 2: 3-15.

Jaroszewski W., Marks L., Radomski A., 1985. Słownik geologii dynamicznej. Wydawnictwa Geologiczne, Warszawa.

Karski T., Frelek-Karska M., Rigo J., 2000. Dobroczynne działanie ciepłych wód w leczeniu chorób narządu ruchu. Technika Poszukiwań Geologicznych. Geosynoptyka i Geotermia, 1: 3-7.

Katsambas A., Antoniou C., 1996. Mineral water and spas in Greece. Clinics in Dermatology, 14(6): 615-618.

Kępińska B., 2010. Stan i perspektywy wykorzystania energii geotermalnej na świecie i w Europie. Przegląd Geologiczny, 58(7): 560-565.

Kępińska B., 2013. Wykorzystanie energii geotermalnej w Polsce, 2012 2013. Technika Poszukiwań Geologicznych. Geotermia, Zrównoważony Rozwój, 1: 5-24.

Kępińska B., 2015. Geothermal Energy Country Update Report from Poland, 2010-2014. Proceedings World Geothermal Congress 2015, Melbourne, Australia, 19-25 April 2015.

Kępińska B., 2016. Przegląd sposobów wykorzystania energii geotermalnej na świecie i w Europie. Czysta Energia, 3: 3-12.

Kępińska B., Ciągło J., 2008. Możliwości zagospodarowania wód geotermalnych Podhala do celów balneoterapeutycznych i rekreacyjnych. Geologia, 34(3): 541-559.

Kępińska B., Łowczowska A., 2002. Wody geotermalne w lecznictwie, rekreacji i turystyce. Polska Akademia Nauk, Kraków.

Kochański J.W., 2002. Balneologia i hydroterapia. Akademia Wychowania Fizycznego, Wrocław.

Kowalczyk A., 2001. Geografia turyzmu. Polskie Wydawnictwo Naukowe, Warszawa. 
Koźmiński C., Michalska B., Szczepanowska E., Górnik K., Marks R., 2013. Zarys turystyki zdrowotnej i uzdrowiskowej. Uniwersytet Szczeciński, Szczecin.

Krasiński Z., 2001. Rynek usług uzdrowiskowych w Polsce. Wyższa Szkoła Zarządzania i Bankowości, Poznań.

Krasiński Z., 2004. Cykle życia uzdrowisk. Patan-Press, Kołobrzeg.

Kurek W., 2007. Turystyka. Polskie Wydawnictwo Naukowe, Warszawa.

Latour T., Smętkiewicz K., 2012. Właściwości fizykochemiczne i chemiczne wód geotermalnych i ich zastosowanie lecznicze ze szczególnym uwzględnieniem wody z odwiertu PIG/AGH-2 w Uniejowie. Biuletyn Uniejowski, 1: 79-93.

Ledo E., 1996. Mineral water and spas in Spain. Clinics in Dermatology, 14(6): 641-646.

Łazarek M., Łazarek R., 2007. Uzdrowiska w Europie. Teraźniejszość i rys historyczny. Wyższa Szkoła Społeczno-Przyrodnicza, Lublin.

Melillo L., 1995. Thermalism in the ancient World. Medicina dei Secoli, 7(3): 461-483.

Mihina A.L., Anderson S.K., 2010. Natural Spa and Hydrotherapy. Pearson, Upper Saddle River, New Jersey.

Omulecki A., Nowak A., Zalewska A., 1996. Spa Therapy in Poland. Clinics in Dermatology, 14(6): 679-683.

Płochniewski Z., 1990. Perspektywy zwiększenia eksploatacji wód termalnych do celów balneologicznych i rekreacyjnych. In: Ney R. (ed.), Możliwości wykorzystania wód geotermalnych w Polsce ze szczególnym uwzględnieniem synklinorium mogileńsko-łódzkiego. Materiały Konferencji w Ślesinie k. Konina, 26-27.10.1990 r. Wydawnictwa AGH, Kraków: 209-215.

Polityka resortu $w$ dziedzinie hydrologii na lata 2008-2015. Ministerstwo Środowiska, Departament Geologii i Koncesji Geologicznych. 2008, Warszawa.
Ponikowska I. (ed.), 1995. Medycyna uzdrowiskowa $w$ zarysie. Watext's, Warszawa.

Sallmann N., 2010. Megatrend wellness \& spa dla rynku ustug wolnego czasu i hotelarstwa $w$ XXI w. Polska Akademia Gościnności, Kraków.

Seung-Kyung H., 1996. Mineral Water and Spas in Korea. Clinics in Dermatology, 14(6): 633-635.

Smith M., Puczkó L. (eds.), 2009. Health and wellness tourism. Elsevier, Oxford.

Szromek A.R., Kapczyński A., 2010. The problem of thermal spas location on the example of Poland. In: Hittmar S. (ed.), Knowledge base for management. Theory and practice. EDIS Vydavatel'stvo Žilinskiej Univerzity: 313-328.

Stanik A., Podlasek B., Raś A., 2011. Przegląd nowych ośrodków rekreacyjnych w Polsce stosujacych wody geotermalne. Technika Poszukiwań Geologicznych. Geotermia, Zrównoważony Rozwój, 1-2: 245-256.

Ślusarczyk J., 2003. Historia turystyki. In: Winiarski R. (ed.), Nauki o turystyce. Studia i monografie, nr 7. Akademia Wychowania Fizycznego, Kraków.

Ustawa z dnia 9 czerwca 2011 r. Prawo geologiczne i górnicze (Dz. U. z 2016 r. poz. 1131).

Warszyńska J., Jackowski J., 1978. Podstawy geografii turyzmu. Polskie Wydawnictwo Naukowe, Warszawa.

Zejszner L., 1844. Carte géologique de la chaîne du Tatra et des soulèvemens parallèles. Schropp, Berlin (published without name).

Zieliński A., 1983. Listy ze śląskich wód. Zakład Narodowy im. Ossolińskich, Wrocław.

\section{Websites}

www.infobasen.pl [accessed: 2015.03.12]

www.topmapa.pl [accessed: 2016.11.15] 